\title{
Re-thinking the Zero Tolerance Approach to FGM/C: the Debate Around Female Genital Cosmetic Surgery
}

\author{
Janice Boddy ${ }^{1}$ \\ Accepted: 28 October 2020 / Published online: 21 November 2020 \\ (C) The Author(s) 2020
}

\begin{abstract}
Purpose of Review To examine the 'zero tolerance' policy for female genital cutting (FGM/C) in the international health community in light of the growing popularity of FGCS (female genital cosmetic surgery) worldwide.

Recent Findings 'Traditional' FGM/C performed in Egypt and Sudan and cosmetic labiaplasty performed in Europe, the Americas, and Antipodes by medically trained gynaecologists and plastic surgeons are based on similar aesthetic logics: labia minora that protrude beyond the labia majora are deemed ugly, masculine, and 'abnormal'. Drawing on the burgeoning medical, social science, and humanities literature surrounding labiaplasty, the paper documents the narrowing of aesthetic standards governing 'normal' genital appearance and finds that, in addition to adult women, thousands of (mainly Caucasian) adolescents have undergone these operations whose long-term health consequences are unknown.

Summary Western heteronormativity, gender binarism, ageism, and the colonial association of protruding labia minora with animality contribute to body image insecurities and fuel the labiaplasty phenomenon, despite the ethical challenge that the procedures are clearly defined by the WHO as type II $(\mathrm{a}-\mathrm{c})$ female genital mutilations.
\end{abstract}

Keywords FGM/C $\cdot$ FGCS $\cdot$ Labiaplasty $\cdot$ Cultural aesthetics $\cdot$ Body image $\cdot$ Gender

\section{Introduction}

In February 2018, I was invited to address faculty and students at Ahfad University for Women in Omdurman, Sudan, home to the independent Babikir Bedri Scientific Association for Women's Studies (BBSAWS). For decades, these two organisations have been at the forefront of efforts to stop female genital cutting (FGC, a term I prefer for its moral neutrality over WHO's FGM/C), practices that have a lengthy history in Sudan and are deeply entrenched in everyday life. Until recently, being infibulated defined Sudanese female identity and informed a woman's sense of self [1-7]. Over the past 30 years, changes have taken place, with more and more families abandoning infibulation (WHO FGM/C type III) in favour of a milder form of cutting locally known as 'sunna'. Ahfad was justly proud of its

This article is part of the Topical Collection on Sociocultural Issues and Epidemiology

Janice Boddy

janice.boddy@utoronto.ca

1 Department of Anthropology, 19 Ursula Franklin Street, Toronto, ON M5S 2S2, Canada role in raising awareness of the harms of FGC and, in partnership with several INGOs, bringing the prospect of abandonment into open debate $[8,9]$. The movement was seeing results. Annual campus celebrations of 'zero-tolerance day' (February 6th) took place the week before I spoke.

My topic that day was the rising popularity in the West of female genital cosmetic surgery (FGCS), specifically the procedure of labiaplasty: the trimming or removal of the labia minora and/or labia majora for aesthetic purposes. When I described the forms and techniques of these procedures (outlined below), it is little wonder that many listeners were aghast. 'But that's FGM/C Type II!' an audience member volunteered. The comment could hardly have been news to the few INGO delegates in attendance. Yet, Sudanese colleagues were clearly appalled. Several of them approached me afterward to ask how FGCS could be lawful in the West given the WHO guidelines and Western countries' universal condemnation of and legal sanctions against FGM/C. The irony and hypocrisy of almost a century of colonial and post-colonial efforts to stop female genital cutting in Sudan rang clear, let alone decades of international campaigning against the practices throughout Africa, the Middle East, parts of Asia, and among their diasporic populations in Europe, the Americas, and the Antipodes [10-16]. Sudanese faculty and activists worried 
that labiaplasty would provide a workaround for families resisting abandonment. While not (yet) available in Sudan, the procedure is offered in Egypt, where FGC is also entrenched.

There are contextual differences between so called traditional and cosmetic forms of female genital cutting; yet, there are numerous areas of overlap and a deep historical matrix in which the practices are enmeshed. In the discussion below, I outline these connections and differences, sampling from the now considerable literature on female genital cosmetic surgery (FGCS). Labiaplasty has seen exponential growth in high-income countries, becoming an industry in its own right ${ }^{1}$; it has also spawned an accompanying industry of academic and professional scholarship, as well as popular debate. I begin by outlining the varieties of and claimed indications for cosmetic labiaplasty, leaning heavily on descriptions from the public webpage of Toronto Cosmetic Clinic, in the city where I live [20].

\section{The Practices}

'Labiaplasty: Enhance your most intimate area and finally feel comfortable with yourself' reads the blurb on the website for the Toronto Cosmetic Clinic. It goes on to explain:

This surgical procedure usually entails a reduction in the size, and an enhancing of the shape of the labia minora, the labia majora, or both. During labiaplasty, one or both sets of labia may be trimmed, reshaped, shortened, made thinner, or corrected to gain symmetry. The procedure is also sometimes referred to as labial reduction or labial beautification.

The clinic offers a suite of operations, starting with 'The Barbie Labiaplasty':

... invented ... in response to women who requested a perfectly smooth look, much like the doll after whom this form of labiaplasty is named.

During this procedure, most or all of the Labia minora (the 'inner lips') are removed to create a completely tight and petite look. By removing this part of the vulva, the labia majora are allowed to close completely, creating a 'single line' opening.

In cases where the labia majora are also enlarged this part of the vulva is also trimmed down to further enhance the streamlined appearance.

\footnotetext{
${ }^{1}$ In 2007, Liao and Creighton noted a fivefold increase in the number of labiaplasties being performed in the UK in the past decade under the NHS [17]. In the USA, ASAPS statistics from 2018 show that labiaplasty was among the fastest growing cosmetic surgery procedures, up 53\% since 2014, and by $18.3 \%$ since 2017 alone [18]. In Australia, annual Medicare claims for labiaplasty more than tripled between 2000 and 2011 [19].
}

Note the words used in the passages above: 'smooth', 'tight', 'enhance', 'corrected', beautification', and 'streamlined'. These terms echo those of Sudanese women in the village where I conducted ethnographic fieldwork in the mid1970s who said that they performed and underwent what the WHO calls 'traditional' genital cutting, including a modified infibulation $\left(\mathrm{FGM} / \mathrm{C}\right.$ type $\left.\mathrm{III}^{2}\right)$, in order to create a smooth, clean vulva with no 'inner flesh'. 'Which is more beautiful', they would ask, 'this?'-whereupon the speaker would open her mouth and drop her chin, exhibiting a slack opening-'or this?'-lifting her chin and closing her mouth so her lips formed a firm thin line. My Sudanese friends rarely allowed themselves to be photographed smiling or laughing for the same reason: to do so would be undignified, ugly: female body orifices properly ought to be closed [1,2]. Here, concepts of beauty and decency intersect. Yet, aesthetic claims and women's agency are often overlooked in discussions of 'traditional' FGC, most of which depict it as 'barbaric ritual' (but see 6 for Sudan and 19 for Egypt). Aesthetics of course are never neutral; as social and cultural constructs, they are inherently political. They empower, subordinate, categorise, and define.

With these points in mind, I return to descriptions of labiaplasty procedures on Tcclinic.com:

\section{Rim Labiaplasty}

Sometimes referred to as "peek-a-boo" labiaplasty, the procedure entails reduction of both the labia minora and labia majora ... However, a small part of the labia minora is allowed to protrude slightly outside the labia majora, or to "peek out". At the same time, a part of the labia majora is left intact around the vaginal opening, to create a natural-looking slight rim.

The primary purpose of this procedure is to create a symmetrical look, remove skin folds, and to remove exceedingly protruding parts of the labia minora. Many women also request this procedure to remove a darker, irregular edge from the labia minora while maintaining a more natural look. (Emphasis mine)

And the Hybrid Labiaplasty, which is a combination of the Barbie and the Rim:

With this option, the labia minora is reduced in size so that the labia majora completely cover it. However, the reduction is less dramatic than it is with a full Barbie procedure. About one centimeter of the labia minora is left intact. This is sufficient for the labia minora not to

\footnotetext{
$\overline{2}$ The modified or intermediate operation was introduced in the 1920 s by British nurse midwives who trained local women as medical midwives (see note 1). It entails less cutting of the labia minora and labia majora than before, and a partial infibulation of the labia majora anterior to the urethral orifice [4].
} 
protrude past the labia majora, allowing the labia majora to close more tightly over the labia minora for a smooth and clean look.

The clinic also offers labia majoraplasty (sometimes simply referred to as majoraplasty):

During this procedure, excess skin is removed to remove sagging and wrinkles, and to create a smooth look, unobtrusive look [sic].

For some women, enlarged labia majora may be visible through their clothing, creating an embarrassing aesthetic. It may also be very uncomfortable in snug pants, or tight garments such as swimsuits. (emphases mine).

Available too are corrections for 'botched labiaplasty' and 'laser depigmentation'. Regarding the latter:

Some women in addition to not being happy with the appearance of their labia may also notice a difference in skin tone along the edges of their labia minora. While this is normal, if it's bothersome to you, laser depigmentation can provide a solution. ... This can be performed alone, or simultaneously with a labiaplasty or other procedures in this intimate area. ${ }^{3}$

Forms of labiaplasty vary by practitioner preference, cost, and level of complexity. In contrast to those described above in which the labia are amputated or their edges trimmed, the more complicated, longer, and therefore more expensive 'central wedge' method involves removing a V-shaped portion of tissue from the centre of each labium and stitching the cut sides together, preserving some of the sensitive outer edge [21]. Other forms include the 'inferior wedge excision/ superior flap', de-epithelialisation, running w-plasty excision and central excision w/Z-plasty, contoured excision w/superior faps to correct clitoral protrusion, and contact laser excision $[22,23]$. There are also the horseshoe procedure and the custom flask, both of which combine labial cutting with reduction or removal of the clitoral hood ([24, 25]; see also [26]).

\section{Indications}

The language on Tcclinic.com is telling, and similar to that on numerous other cosmetic surgery websites (e.g. realself.com, myplasicsurgeon.com): targeted vulval tissue is depicted as enlarged, excessive, extra, loose, redundant, dark, misshapen, asymmetrical, and/or overdeveloped. Ideally,

\footnotetext{
${ }^{3}$ Related procedures on offer include non-surgical laser labia tightening, labia puffing, clitoral hood reduction, G-Shot ${ }^{\circledR}$ injection, hymenoplasty and hymen restoration, vaginoplasty, and laser hair removal.
}

one's labia minora, these sites suggest, are small, identical in size, and do not protrude beyond the outer lips. Such descriptions do two things: (1) imply that there exists a standard for female genital appearance, a norm from which some female bodies depart; and (2) uphold the (in this case Western, but otherwise common) cultural construction of sex as strictly binary, where genitals are or should be unambiguously male or female, 'discrete and non-overlapping biological entities that confer femaleness and maleness, two forms of existence also constructed as discrete and non-overlapping' ([27]:3). Exploration of the first point entails the second, but also leads to reflection on colonial comparisons between white and racialised female bodies. I start with the binary imperative and the concept of genital normality, then take up the issue of race via the specious notion of 'labial hypertrophy'.

\section{Troublesome Binaries}

In wealthy countries with robust medical systems, a baby born with 'ambiguous genitalia' is regarded as an 'emergency' and more often than not subject to cosmetic surgical intervention to 'normalize' its appearance [27-32]. Although current international recommendations are to postpone sex normalising treatment until the affected person can give informed consent, ${ }^{4}$ social pressures on physicians and parents are so great that, at least in the UK, 'genital surgery on children with atypical genitalia remains part of standard medical care' ([34]:2). Few such cases are life-threatening, yet physicians typically seek to intervene by reducing the size of a clitoris they deem 'too large', with 'overall appearance' counting more than actual size ([28]:60). Despite considerable natural variation in genital appearance, 'one is either a girl or a boy; each identity is discrete and shall not be confused with or be remotely similar to the other' ([30]:166). As such, 'atypical genitalia pose a threat to the infant's culture, to the binary system of classification we hold so dear ... and thus surgical intervention serves aesthetic-politico purposes rather than strictly medical ones' ([31]:402; see also [33]).

Western societies are not alone in constructing sex and sexuality in strict dualistic terms or requiring disambiguating intervention. In Sudan, for instance, the immediate goal of FGC is to remove vulvar tissue that is deemed masculine and, with infibulation, to partly cover the vaginal opening, while male genital cutting (circumcision) de-feminises a child by removing his foreskin, the 'veil' or 'cover' of the penis $([1-3,6])$. The traditional operations on boys and girls in prepubescence (usually between the ages of six and ten)

\footnotetext{
${ }^{4}$ Jafar ([33]:2) notes that California lawmakers introduced a bill in January 2019 to ban non-medically necessary genital surgeries on intersex children and minors until they are able to give informed consent. However, the bill has been stalled owing to objection by The Society of Pediatric Urology, which claims that it would abrogate parental rights.
} 
complete their gendered bodies and help set their adult orientations. Although the incidence of FGC has declined in Sudan, the ideal female body in the village where I lived in the mid1970s and 1980s was one whose genital area was smooth and clean, lacked protrusions, had everything hidden and neatly tucked away. As Abusharaf reports (and my interlocutors would concur), the ideal outcome would be a genital area 'smooth and beautiful like the back of a pigeon' ([6]:122). Provocatively, one might regard the rise of labiaplasty as enabling adult women in the West to emulate what Sudanese girls experienced in their youth.

But this is not precisely the case. In Europe and North America, FGCS is performed on girls as young as ten, well before their bodies are fully grown, and websites abound with teens voicing anxiety about their 'abnormal' netherparts. Recent headlines read 'Doctors Warn That Teen Labiaplasty Is On The Rise' and 'More Teenage Girls Seeking Genital Cosmetic Surgery' ([35, 36]; see also [32, 37-40]). One Spanish doctor reporting on sixteen underage labiaplasty patients whose median age was 13.43 years claims that 'hypertrophy of the labia minora' is a 'growing problem in adolescence' [41]. The American Society for Aesthetic Plastic Surgery (ASAPS) reports that between 2015 and 2017, 1428 girls aged 18 and younger underwent cosmetic labiaplasty, and (owing to a change in data collection methods) 491 girls 17 and under in 2018 [18]. The International Society for Aesthetic Plastic Surgery (ISAPS) Global Survey notes that in 2018, only $37 \%$ of labiaplasties in the USA were carried out by plastic surgeons; many more were performed by GPs or cosmetic gynaecologists ([42], and see [43-46]). As such, most procedures would have been done in private clinics and there is no duty to report; numbers and ages are unavailable, but there is little reason to doubt that a comparable proportion - conservatively $4 \%$ of labiaplasties in the USA according to ASAPS statistics - was performed on girls and teens [18].

Concerned physicians Runacres and Wood report that '297 labial reductions [were] carried out by the National Health Service in the United Kingdom between 2008 and 2012 in children younger than the age of 14 for unknown reasons and with unknown outcomes' ([47]:218). Simonis et al. report that about a third of GPs in a large UK study had received requests for referral for FGCS from girls under the age of 18 [48]. In 2013, the British Society for Paediatric and Adolescent Gynaecology issued a position statement advising that 'in the absence of an identifiable disease and until evidence demonstrates to the contrary, labiaplasty should not be performed on girls under the age of 18 years' as their genital growth is incomplete ([49]:2; also 49:5). By contrast, in 2016, the American College of Obstetricians and Gynecologists (ACOG) reversed a previous stance against teen labiaplasty by acknowledging its utility 'in adolescents under 18 who experience persistent psychological distress or physical symptoms of discomfort, irritation and pain' ([50]; see also [51-53]). ${ }^{5}$ We must conclude that over the past decade or more, thousands of adolescents around the world have undergone labiapasty. While their numbers may pale beside the three to four million girls deemed annually at risk of FGC, they are troubling nonetheless [54]. Michala identifies adolescent genital dissatisfaction (GD) to be a growing trend, indirectly indicated by the increasing popularity of FGCS [53]. Controversy surrounding the ethics of underage labiaplasty and its potential classification as FGC may be why ASAPS, recently renamed The Aesthetic Society, listed zero procedures on girls 17 years and under in 2019 [55].

The inconsistencies are patent: juvenile labiaplasties together with medically unnecessary intersex gender surgeries, both performed in the West on minors with parental consent, completely elude the legal sanctions imposed on medically unnecessary genital modifications performed on girls in African and Asian diasporic communities, even when the procedure is as mild as a nick to the clitoral hood and could be considered vital to a girl's psychological well-being and community membership $[10,13,16$, $29-31,33,56-60] .{ }^{6}$ This blind spot is an example of what Gunning calls 'arrogant perception' and Sullivan refers to as 'white optics', an embodied historically and culturally specific, ultimately colonial, way of knowing and being that empowers elites to see others as culturally different while blinding them to the fact that they themselves are culturally formed $([31,61]: 397 ;[3,62])$. Hegemonic Western constructs are naturalised, imbued with ontological certainty, taken-for-granted, and thus both inevitable and invisible. In the cases of FGCS and intersex surgery, cultural binarism bolstered by the authority and power of biomedicine forms an inexorably tangled mix.

Why the rise in vulval dissatisfaction among women and teens in the West? In her 2019 book tracing the arc of Western thought about female genitals, Camille Nurka asserts that 'cosmetic labiaplasty is merely another proposed solution, in the long history of gynaecological medicine, to female sexual deficit thought to spring from a woman's own defective body' ([32]:187). Following Mary Douglas, she notes that human bodies are inherently ambiguous; they excrete and exude; they resist boundedness [32, 63, 64]. Excrement, menstrual blood, bodily fluids that are uncontained are classed as dirt in Western and many other cultural imaginations. As Douglas

\footnotetext{
5 A clause in the 2017 revision (and 2020 affirmation) of this opinion reads 'surgical alteration of the labia that is not necessary to the health of the adolescent, who is younger than 18 years, is a violation of federal criminal law' referring to the Female Genital Mutilation 18 Act, U.S.C. 116 (2015), a law that was deemed unconstitutional in 2018.

6 This begs consideration of male circumcision as a form of traditional gender surgery that is typically exempt from laws against genital mutilation. See Earp, Current Sexual Health Reports, this volume.
} 
famously wrote, 'dirt is matter out of place', bodily matter that does not remain inside defies propriety and social order ([63]:44). Moreover, there is no clear distinction between what is inside and what is out where female genitals are concerned. 'Culturally', writes Sara Rodrigues, 'we have learned to see the [vulva] in such a way that its parts cannot be distinguished in the same, unambiguous way that testicles can be isolated from a penis' ([65]:782). Being located between the interior and exterior of the body as well as prone to leakage, the vulva is doubly ambiguous, and often characterised in negative terms, as dirty, smelly, disgusting, disruptive to 'the clean and proper body' [32, 65-69]. It is hardly surprising that many women have conflicted feelings about this anatomical part; indeed, the entire industry of feminine hygiene products is founded on the 'truth' of the vulva's impurity [70, 71].

When parts of the vulva protrude beyond assumed body boundaries, their appearance confounds the binary logic of distinctly male and female, masculine and feminine kinds. In the mid-1970s, feminist anthropologists-e.g., Sherry Ortner, Michelle Rosaldo, Rayna Reiter (Rapp), Gayle Rubin-explored the cross-cultural implications of gender binarism, paving the way for feminist theorists such as Susan Bordo and Judith Butler to expose how gender identity is formed by constrained iterative performance and thereby naturalised, made to seem inevitable, tied to seemingly pre-cultural facts of sex ([72-77]; also [78]). Yet, our understandings of biological sex are already thoroughly cultural and therefore gendered: there is no Archimedean vantage from which to view and judge. While there must be, as Nurka notes, 'an extracultural quality to sex as a material facticity', this is not uninflected, nor is it strictly binary or dimorphic ([32]:204). For Rubin and Butler, the binary sex/gender system rests on the principle of 'compulsory heterosexuality', a logic that limits the spectrum of desire and directs plural human possibility into opposed categories based on the distinction between penis and vagina, active penetrating male and passive penetrated female $[74,76]$. In feminising operations performed on intersex infants, the undersized penis/oversized clitoris is reduced and a vaginal opening constructed or expanded (often over several surgeries) to accommodate a penis of normal length ([28]:61, 30). Heterosexual dimorphism is thus created as it is affirmed. Likewise, websites advertising labiaplasty tacitly assume that candidates for the procedure are women (and girls) seeking to look 'more feminine' in the context of an ongoing or anticipated heterosexual relationship. As the procedures remove sensitive, sexually responsive outer tissue, they emphasise the internal, penetrable vagina as the locus of female sexuality and sexual difference, reinforcing heteronormative homogeneity [30, 79]. Despite their incommensurable contexts, this is not dissimilar to how infibulation in Sudan emphasised the vagina and women's reproductive potential by potentially attenuating their sexual response $[1,2] .^{7}$

In addition to labiaplasty, a host of cosmetic surgeries to enhance and maintain dimorphic appearance is increasingly performed especially, but not solely, in high resource countries. In the USA, reduction treatment for gynaecomastia (male breast enlargement) rose $47.9 \%$ between 2014 and 2018 , up to $22.3 \%$ from 2017 alone, for just under 25,000 cases in 2018. The majority of cosmetic enhancements, however, are performed on women: $86.5 \%$ worldwide according to ISAPS statistics for 2018 [42]. In the USA, rates of female buttock augmentation rose by $61 \%$ between 2014 and 2018 (over 30,000 cases), outpacing the growth of labiaplasty by $8 \%$. Yet, these figures hardly compare to those for female breast augmentations (up to $15.2 \%$ ) and breast lifts (up 55.9\%), which together numbered almost half a million procedures in the USA in 2018 [42]. The contemporary womanly body ideally has rounded buttocks, large breasts, and a vulva that exemplifies a 'clean-slit aesthetic ... of absence and smoothness, with no external structures visible' ([80]:776; see also $[14,17,19,22,38,66])$. It is a body that resembles a Barbie doll.

It is also hairless, true as well for women in Egypt and Sudan. Unsurprisingly, among the procedures on offer at the Toronto Cosmetic Clinic is laser hair removal; currently, Western women, and younger women in particular, are strongly pressured to rid themselves of pubic hair ([59, 81-85]). In studies from 2009 and 2012, some 84\% of younger women were reported to remove their genital hair ([83]:170; [86, 87]). Several store-front clinics advertise 'Brazilian' genital depilation in my neighbourhood alone. Yet, such procedures are not benign. By waxing pubic hair, 'soft, previously unexposed genital skin [is revealed], increasing its vulnerability to trauma, skin infections, chafing and rubbing' ([81]:109). The practice aligns with the fashion for revealing clothing such as string bikinis, thong underwear, and tight fitting exercise pants, yet renders visible and prone to injury what by nature would be protected and concealed from view. Women who decades ago may not have noticed that their labia 'protrude', do so now, and may experience discomfort performing various activities that eliminating this hairy buffer creates. They are thus candidates for labia reduction. As Liao and Creighton pithily observe:

Binary notions of the genitals explain why men, who on average have a greater share of the burden of genital mass, tend not to complain about the kind of rubbing and chaffing of the genitals that bother women, nor are men known to have their genital mass surgically reduced to accommodate sporting activities such as cycling and horseback riding ([27]:4).

\footnotetext{
${ }^{7}$ This is not, of course, intended to endorse either form of genital modification, only to note their similar logics.
} 
Although some women and girls seek labiaplasty to alleviate (arguably self-inflicted) pain, for the majority, aesthetic issues take top billing. In an Australian study, close to three quarters of women desiring labiaplasty voiced concern about their labia's appearance; this was followed by nonsexual functional difficulties, difficulties with sexual intercourse/sexual relationships, and psychological issues ([88]: 473; see also $[46,89,90])$. In Spain, Surroca reported that $81 \%$ of her labiaplasty patients cited aesthetic concerns, while aesthetic dissatisfaction accounted for $87 \%$ of labiaplasty requests in Bramwell and Morland's UK study of 2009 [91, 92]. It is difficult to disaggregate these rationales, as body image and self-confidence are crucial for sexual well-being. Moreover, as Liao and Creighton note, 'women's intolerance of the physical sensations of their labia is at least partly informed by a psychological 'discomfort' about how their genitals present' ([93]:7).

The expansion of surgical practices that amplify the appearance of binary difference is remarkable and somewhat ironic in societies that purport to welcome bodily diversity, transsexuality, and same sex relationships, indicating, perhaps, the countervailing strength of a heterosexist ideal. It also attests to the neoliberal moment that enjoins individuals to view their body as a project and commodity [71, 75, 84]. As Virginia Braun points out, rhetoric surrounding labiaplasty 'frames it as a practice for the self - an act you can choose as part of a general project of improvement of the body/self' ([71]:24, original emphasis). Ever expanding opportunities to sculpt one's appearance coincide with ever more restrictive aesthetic ideals and constrained notions of what is natural, seemly, indeed normal [10]. 'Despite women being positioned as having power and freedom', Moran and Lee observe 'their actual choices are increasingly limited by narrow, heterosexist and homogenized representations of female sexual being' ([84]:230). Choice, the factor touted as distinguishing 'traditional' from 'cosmetic' female genital cutting, is never contextless or 'free' [3, 57, 59]. Moreover, the cosmetic surgery industry, a product of twentieth century medical advance, serves an overwhelmingly female population for whom its 'mere existence ... creates the very anxieties that surgery is claimed to dispel' ([84]:230, also [57]).

\section{Evolving Concepts of Normality}

By what standard do women who seek labiaplasty judge themselves deficient? Natural labia fall within a wide range of sizes and shapes - as captured in Jamie McCartney's art piece, 'Great Wall of Vagina' ([94]; also [71]:84) - and there is no medical consensus on what constitutes abnormality [95-99]. Sarah Rodriguez documents shifts in medical discourse during the late twentieth century into the early twenty-first from doctors reassuring patients that their labia fall within the bounds of human diversity and seldom advising reduction, to accepting patients' assessments that their labia are too large and require surgical intervention to 'correct' [100]. Criteria determining, counterintuitively, whether a 'natural' vulva needs 'surgery to render it normal' are therefore subjective; surgeons are no less affected by cultural models of genital appearance than their patients or the rest of the population [84]. Not surprisingly, then, thresholds for surgery have narrowed over time. In the first systematic study of vulvar anatomy, Lloyd et al. measured fifty mainly Caucasian pre-menopausal participants in the UK, finding that their labia minora ranged from 7 to $50 \mathrm{~mm}$ in length with none having expressed 'personal difficulty or sought cosmetic alteration' ([97]: 644, 645). ${ }^{8}$ Before the twenty-first century, labial hypertrophy was defined as a maximal width exceeding $5 \mathrm{~cm}$ [101]. Writing in 2000, a group of French gynaecologists deemed labia minora to be 'hypertrophic' or enlarged 'when the maximal distance between base and edge was greater than $4 \mathrm{~cm}$ ', concluding that despite 'hypertrophy of the labia minora' not being 'pathological', 'when the patient has aesthetic or functional concerns, labia minora reduction should be proposed' ([89]:35, 39). In 2006, Munhoz et al. advised $3 \mathrm{~cm}$ as the basis for surgery [102]. And in 2017, German plastic surgeon Stefan Gress recommended anything exceeding $2 \mathrm{~cm}$, as this is when they may be "visible outside the shelter of the labia majora'. As such, they are 'associated with more detrimental physical and psychological effects... [and] can be described as hypertrophic' ([95]:6). Swiss surgeon Stéphane Smarrito referred to labial hypertrophy as 'a well-known pathology', and classified oversized labia based on shape and position within the vulva, since 'the position of the labia minora in relation to the labia majora seems ... to be the principal criterion of normality in the eyes of patients' ([103]; see also [21, 22, 89]). Finally, a group of surgeons in Spain claimed that while hypertrophy of the labia minora is 'a little known disease', it is becoming more common among adolescents [41].

However, as Liao and Creighton note 'there is no reason to believe that the size of the labia minora has increased in the past decade. There is also no suggestion that the labia minora have recently become more prone to diseases' ([93]:7). Crouch suggests that the term hypertrophy 'sounds reassuringly medical, yet lacks any definition or validation' ([96]:20). Still, ever greater amounts of healthy genital tissue are being defined as 'redundant', 'excessive', 'enlarged', 'misshapen', 'overdeveloped', even, as Smarrito writes, 'pathological', and 'deformed' [103]. Plastic surgeons who critique 'hyertrophy' use the word nonetheless [98]. As Triana astutely observes, labiaplasty is not performed to correct genital malformation

\footnotetext{
${ }^{8}$ More recently, Kreklau et al. examined 657 Caucasian women of varying ages and weights and found average labial width (what would be considered length when standing) of between 13.4 and $14.15 \mathrm{~mm}$, with maximums between 42 and $61 \mathrm{~mm}$ ([101]:1658).
} 
any more than cosmetic breast augmentation is performed to correct malformation of the female breast [104]. Rather, both procedures are intended to improve a patient's self-image, the fit of her body with the cultural ideal. Indeed, the UK Female Genital Mutilation Act that criminalises traditional FGC actually supports FGCS by stipulating its legality in the event that a woman's distress is 'caused by the perception of abnormality; actual abnormality or pathology is not required' ([59]:74, original emphasis).

The diagnosis of labial hypertrophy exemplifies what philosopher Ian Hacking calls dynamic nominalism, a looping process by which as new modes of description come into being, new possibilities for action arise [105]. The cisgendered 'hypertrophic' woman came into being as a 'kind of person' at the same time the kind was being invented; a community of experts-plastic surgeons, cosmetic gynaecologists - created a 'reality', backed by allegedly objective measurements and statistics that some women came to inhabit just as women with genital dissatisfaction sought a solution to their newfound distress. Once 'under a description' their recourse, funds permitting, was clear.

Some feminist critics, as well as surgeons themselves, claim that Internet exposure to heterosexual male-oriented pornography has helped spur women to seek labia reduction $[17,30,57,67,82,106]$. Soft-core films and magazines typically feature images of women with hairless genitals that have been surgically trimmed or digitally altered, in part to conform to government censorship rules where, as in Australia, showing genital detail is defined as obscene. 'Think of it as 'digital labiaplasty", wrote journalist Kirsten Drysdale ([107]; see also [108, 109]). Surgeons report that women arrive at their clinics with pictures of 'ideal' but often photoshopped vulvas taken from Playboy, Penthouse, or the Internet, asking doctors to make them look 'like that', 'normal', 'tidy', and 'neat' [40, $80,107,109,110]$. Jones and Nurka convincingly argue that vulvas depicted in still-image high-end glossy porn do not cause women's genital discontent so much as reflect enduring cultural disgust for the labia, and may thus be 'illustrative, rather than generative' ([111]: 64; also [19, 71, 84]). Veale et al. report that only $12 \%$ of their sample of fifty-five women seeking labiaplasty had viewed porn; however, they speculate that other forms of media, including 'television programmes, such as 'Embarrassing Bodies' in the UK, and coverage in women's magazines normalises and legitimises labiaplasty and may fuel the demand' ([112]:61; see also [113, 114]). So too may the legion of cosmetic surgery sites like Tcc. com, which portray idealised vulvas and advertise their availability, at a cost, with financing available. Such sites urge women to 'normalize' and thus discipline their bodies: to 'choose to be normal' $[57,59,65,71]$.

In an interesting demonstration of how media and body discipline intersect, Placik and Arkins analysed all Playboy centrefold images between January 1954 and December
2013, finding that focal emphasis generally shifted over time from the breasts to the vulva, depicted as hairless. In centrefolds from 2000 on, exposure of the labia majora increased dramatically, yet from 2006, visibility of the labia minora declined (from 8.7 [ 9 photos] to $4.8 \%$ [2 photos]), corresponding to the growth of labiaplasty and reinforcing the 'idealized norm' [115].

Several other studies reveal the intersections of media imagery and women's views of normal and ideal vulvas. Howarth et al., for instance, showed a group of young Australian female university student photos of women's bodies naked from hips to thighs, and were concerned 'that all 21 participants identified a photograph depicting hairless genitalia with no visible labia minora as the 'socially accepted' ideal vulva' and several 'felt this representation was normal and that any pubic hair or protruding labia minora were undesirable or unclean' ([19]:1375; see also [68, 84]). Sharp et al., comparing responses from women seeking labiaplasty to those from a group who were not, found that the former had 'been exposed to a greater volume of these idealized media images and display a stronger desire to resemble these images than women not seeking labiaplasty' ([88], see also [85]). This is surely a case for how contemporary power 'works in and through the production of subjects/selves and desires' ([57]:236; [65]), even if the process does not remain unchallenged [116].

The relationship between media exposure and desire for labiaplasty is undeniably close. According to Meredith Jones, the digital era produces 'media-bodies' that ravel flesh and image, three-dimensional reality, and two-dimensional representation, to the point where media and bodies are 'mutually constitutive'. She notes that some respondents 'wish they could be Photoshopped in real life' ([65]:45-46). Camille Nurka argues that 'surgically altered genitalswithout-labia are a post-human phenomenon in a world in which we strive to leave the messy, hairy business of the biological body behind' ([32]:14). The 'we' in this provocative statement leads to a discussion of the historical context for labiaplasty in the Western here-and-now.

\section{Race}

Vulvas in Western cultures are not only abject, they are also classed, raced, aged, and compared to others of their ilk. The majority of women depicted on labiaplasty websites are relatively young and white. In a marathon examination of just under 500 sets of before and after pictures on RealSelf.com, I counted only a handful of women who could be identified as black or brown [117]. One wonders if labial dissatisfaction is mainly a problem of Caucasian elites, managed by pricey elective surgery seldom paid for by government medical plans. 
Several authors argue that Western constructions of the 'normal' vulva are informed by 'the conspicuous presence of the black other' ([114]:418, [32, 64]). Indeed, the origins of current medical discourse surrounding 'labial hypertrophy' can be traced to the colonial past, to nineteenth century European naturalists fascinated by accounts of large vulval structures among Khoisan peoples of southwest Africa (pejoratively called Hottentots). Such accounts, and especially the spectacle of Saartjie 'Sarah' Baartman, a 'Hottentot' woman brought to London as a circus attraction in 1810, helped fuel the period discourse of 'scientific racism', a pseudoscientific debate over whether races were different species or descendants of the original perfect couple, Adam and Eve, whose ancestors had 'degenerated' over time. As Nurka notes in her detailed historical account, such explanatory models 'sought to explain blackness as degenerate, animal and uncivilized in order to justify white colonial domination and enslavement of black peoples' such that the aetiology of labial hypertrophy 'cannot be separated from the racist discourses through which it came to attain its meaning as excessive, bestial, or 'of nature', and beyond the bounds of that which was considered appropriate to the 'normal', white body' ([32]:92, [32]:112). Unsurprisingly, nineteenth century European naturalists argued that practices of female genital cutting in Egypt (which would have included today's Sudan) had a racist rationale: to correct hereditary genital hypertrophies that obstructed sexual relations ([32]:114). The 'contemporary practice of cosmetic labiaplasty', Nurka argues, 'is the resignification of an old colonial fear - of white femininity threatened by racial contamination' that shows itself in body shame ([32]:116). Before and after shots on cosmetic surgery websites document the elimination of tissue that is ostensibly repulsive, exotic, and dark. The result is homogeneous, pink, neatly tucked-in 'normal' genitals, presumably superior in every way. In some regions (including Sudan), a colonial holdover of 'white supremacy' links pale skin with beauty, and despite significant counter measures, skin-bleaching products are aggressively marketed and widely used with adverse consequences for health [118]. Moreover, the desire for a youthful, smooth, prepubescent look is also linked to Western anti-ageing concerns $([10,23,80]$ and numerous labiaplasty websites).

\section{Medical Concerns}

Labiaplasty is an irreversible operation that carries risks, many of them shared with 'traditional' forms of FGC. Although robust data are sparse, complications can include infection, persistent bleeding, haematoma, fistula, wound separation, and overtightening, affecting between $4 \%$ and $18 \%$ of patients [83]. The procedure can be 'botched' and roughly one in ten US surgeons report having to perform re-operations [119]. Indeed, websites advertising revisions for 'botched labiaplasty' abound, complete with their own before and after shots (e.g. [120, 121]). Keloids can form, and neuroma-like hypersensitivity may develop. Many of the operations are performed on nulliparous young women, and as Michala notes, little is yet known about how a previous FGCS will affect childbirth. "Will there be a higher incidence of perineal tears, ... how will pregnancy or labour and delivery affect the result of a previous FGCS?' ([119]:56). The Royal Australian College of General Practitioners warns that the scar itself could separate during birth ([119]:53; see also [14, 15, 22, 90]).

Some practices, such as 'direct excision', described on the Toronto website above, may lead to visible scar formation, loss of sensation, and compromised neurovascular supply which, since the labia minora play a role in sexual arousal, can affect the ability to achieve orgasm; dyspareunia (painful intercourse) and reduced lubrication can also occur ([22, 81, $119,122,123]$, but see [124]). Yet, advertising for labiaplasty often claims that, post-operatively, sexual response will be enhanced, a claim that the implications of self-esteem for sexual health cannot entirely dispel $[27,106]$.

The dearth of systematic data about problems attending labiaplasty is more than made up for by an abundance of literature on complications of 'traditional' FGC. Yet, much of this, as Obermeyer observed, is unreliable, sensationalised, and overblown, including that which claims that sexual pleasure is inevitably impaired ([125, 126], also 6, [127]). Importantly, traditional forms of FGC can continue precisely because they are seldom immediately lethal, though they are certainly painful, dispose women to infection, and, if infibulation is involved, typically require complex episiotomy for birth [3]. In several areas where FGC occurs, parents have turned to medical professionals to perform the operations. While the medicalisation of FGC is resisted by international organisations worried that scientific cachet lends the procedures unwarranted support, concern to maintain hygienic standards, control the amount of tissue removed, and prevent complications has led parents to request that operations be conducted by doctors, nurses, or trained midwives; many have complied, some for profit, others anxious that untrained practitioners would do a child greater harm. As Kimani and ShellDuncan show, rates of medicalised FGC are rising, and are highest in Egypt (38\%) and Sudan (67\%) ([128]:26). In Kenya, medicalisation has undermined efforts encouraging total abandonment [129], a problem my activist audience at Ahfad were familiar with as well.

The medicalisation of FGC is but a small off-centre part of a global phenomenon: the extension of biomedicine - surgeries, pharmaceuticals, medical labelling - into ever more areas of daily life, far beyond its earlier focus on preventing and treating disease. Biomedicine is currently invoked to address what once would have been viewed as social or moral issues, or 'part of the spectrum of normality, or an inevitable stage of 
aging', such as menopause, age-related erectile dysfunction, and ADHD ([130]:114). By transforming aspects of everyday life into pathologies, medicalisation narrows the range of what is judged acceptable, 'focuses the source of the problem in the individual', and calls for 'individual medical interventions rather than collective or social solutions' ([131]: 7-8; also [132]). The medicalisation of sexual intimacy encompasses the use of Viagra, Cialis, and similar drugs by young men wanting to enhance sexual performance or older men seeking to regain youthful potency and boost self-esteem. Included too are all forms of FGCS: vaginal tightening, hymen repair, clitoral repositioning, and of course labiaplasty, whose link to youth, indeed prepubescent, sexually innocent youth, is all too clear. In focussing on technical solutions for problems that are social, cultural, and psychological at heart, the neoliberal biomedicalisation of intimacy is a perfect 'anti-politics machine', disguising social and political problems (ageism, female objectification and subordination) as individual pathologies that can be fixed, at a price (see [133]).

\section{Conclusion}

To return to the issue with which I began, what does it mean to adopt a 'zero-tolerance' approach to traditional female genital cutting in an era when medicalised female cosmetic genital cutting is gaining purchase and respectability worldwide? How do we continue to differentiate legally and ethically between the two when issues such as underage 'consent', choice, cultural aesthetics, and political context so consistently overlap? I close with two observations.

An important qualitative study of health professionals and mothers of cut girls in Egypt shows that the language of cosmetic labiaplasty has been taken up by doctors and nurses who perform FGC. Omaima El-Gibaly and her team sought to understand why in Egypt medicalised FGC among girls under age 19 rose from 55\% in 1995 to $74 \%$ in 2014. They discovered that for several reasons, both mothers and health care workers considered FGC 'an important cultural obligation', but for my purpose, one finding stands out. Both male and female doctors 'repeatedly referred to 'beauty' and 'ugliness' in regard to girls' genitals' and indeed, 'many physicians who performed FGM/C denied that they practiced FGM/C, preferring to refer to the procedure as 'a cosmetic operation' instead' ([134]: 2, 4, 8-9). Below are illuminating excerpts from their informants' statements:

I don't call it circumcision, I call it 'refinement'. For me as a doctor, I don't do this case as female circumcision, I do it as a technical case. ... I do this refinement or cosmetic operation.

This is not considered circumcision ... but you are beautifying the labia. It's normal.
Look, the normal size is that when the labia majora are closed. Nothing is protruding from them. ... [I]f there are protrusions outside the labia majora, there would be a need [to cut the girl] ([134]:9).

As the authors note, this reframing of FGC as cosmetic surgery serves to legitimise the practice. It offers a way to promote it to mothers, and circumvent Egypt's law against FGM/ $\mathrm{C}$, which does not penalise FGCS among young women over the age of 18 ([134]:10).

Last, it is widely reported that 'traditional' FGC occurs in 31 countries, most of them in Africa, the Middle East, and Asia [54]. My latest exploration of the Dublin website WhatClinic.com, where cosmetic surgery firms advertise worldwide, yielded 847 labiaplasty clinics distributed over 68 countries, among them several in Africa, the Middle East, and Asia [135]. Not all of these countries are highly resourced (they include Jordan, Peru, Albania, Malaysia, Indonesia, and Nepal). I found advertisements for 13 clinics in Egypt alone. So, as global rates of FGCS rise and those of FGC slowly decline, it behoves us to address all forms of female genital cutting proportionately and dispassionately, setting aside ethnocentric hubris and medical mystique, lest we betray dedicated local anti-FGC activists like those who attended my Ahfad University talk in 2018.

\section{Compliance with Ethical Standards}

Conflict of Interest The author declares that she has no conflicts of interest.

Open Access This article is licensed under a Creative Commons Attribution 4.0 International License, which permits use, sharing, adaptation, distribution and reproduction in any medium or format, as long as you give appropriate credit to the original author(s) and the source, provide a link to the Creative Commons licence, and indicate if changes were made. The images or other third party material in this article are included in the article's Creative Commons licence, unless indicated otherwise in a credit line to the material. If material is not included in the article's Creative Commons licence and your intended use is not permitted by statutory regulation or exceeds the permitted use, you will need to obtain permission directly from the copyright holder. To view a copy of this licence, visit http://creativecommons.org/licenses/by/4.0/.

\section{References}

1. Boddy J. Womb as oasis: the symbolic context of pharaonic circumcision in rural northern Sudan. Am Ethnol. 1982;9(4):682-98.

2. Boddy J. Wombs and alien spirits: women, men and the zar cult in northern Sudan. Madison: University of Wisconsin Press; 1989.

3. Boddy J. Violence embodied? Female circumcision, gender politics, and cultural aesthetics. In: Dobash R, Dobash R, editors. Rethinking violence against women. Thousand Oaks: Sage; 1998.

4. Boddy J. Civilizing women: British crusades in colonial Sudan. Princeton: Princeton University Press; 2007. 
5. Gruenbaum E. The female circumcision controversy: an anthropological perspective. Philadelphia: U Pennsylvania Press; 2000.

6. Abusharaf RM. Virtuous cuts: female genital circumcision in an African ontology. J Feminist Cult Stud. 2001;12(1):112-40.

7. Kenyon S. Five women of Sennar: culture and change in central Sudan. Long Grove, Ill: Waveland; 2004.

8. World Health Organization (WHO). Working towards zero tolerance for female genital mutilation in Sudan. 2018. https://www. who.int/news-room/feature-stories/detail/working-towards-zerotolerance-for-female-genital-mutilation-in-sudan Last accessed Aug 30, 2020.

9. Boddy J. Engendering social change: new information technologies and the dynamics of gender in northern Sudan. In: Hale S, Kadoda G, editors. Networks of knowledge production in Sudan: identities, mobilities, and technologies. Lanham: Lexington; 2016.

10. Boddy J. The normal and the aberrant in female genital cutting: shifting paradigms. HAU: J Ethnographic Theory. 2016;6(2):95119.

11. Weil Davis S. Loose lips sink ships. Fem Stud. 2002;28(1):7-35.

12. Manderson L. Tensions between cultural diversity and human rights. Int Fem J Polit. 2004;6(2):285-307.

13. Johnsdotter S, Essén B. Genitals and ethnicity: the politics of genital modifications. Reprod Health Matt. 2010;18(35):29-37.

14. Berer M. Labia reduction for non-therapeutic reasons vs. female genital mutilation: contradictions in law and practice in Britain. Reprod Health Matt. 2010;18(15):106-10.

15. Berer M. Cosmetic surgery, body image and sexuality. Reprod Health Matt. 2010;18(35):4-10.

16. Kelly B, Foster C. Should female genital cosmetic surgery and genital piercing be regarded ethically and legally as female genital mutilation? BJOG. 2012;119:389-92.

17. Liao LM, Creighton SM. Requests for cosmetic genitoplasty: how should healthcare providers respond? BMJ. 2007;334:1090-2.

18. American Society for Aesthetic Plastic Surgery (ASAPS). ASAPS-stats 2014, 2015, 2016, 2017, 2018.pdf. https://www. surgery.org/media/statistics. See also The Aesthetic Society from 2019 (same url).

19. Howarth C, Hayes J, Simonis M, Temple-Smith M. 'Everything neatly tucked away': young women's views on desirable vulval anatomy. Cult Health Sex. 2016;18(7):1363-78.

20. Toronto Cosmetic Clinic. https://www.tcclinic.com/surgical/ labiaplasty/ Last accessed 1 Sept. 2020.

21. Alter GJ. Aesthetic labia minora and clitoral hood reduction using extended central wedge resection. Plast Reconstr Surg. 2008;122(6):1780-9.

22. Motakef S, Rodriguez-Feliz J, Chung MT, Ingargiola MJ, Wong VW, Patel. Vaginal labiaplasty: current practices and a simplified classification system for labial protrusion. Plast Reconstr Surg. 2015;35(3):74-788.

23. Kavouni I, Creighton S. Techniques of female genital cosmetic surgery. In: Female Genital Cosmetic Surgery: Solution to What Problem? Cambridge: Cambridge University Press; 2019.

24. Oppenheimer AJ. The horseshoe labiaplasty. Ann Plast Surg. 2017;78:S286-8.

25. Gonzales F, Dass D, Almeida B. Custom flask labialasty. Ann Plast Surg. 2015;3:266-71.

26. Gress S. Composite reduction labiaplasty. Aesthet Plast Surg. 2013;37:674-83.

27. Liao LM, Creighton SM. Female genital cosmetic surgery: solution in pursuit of a problem. In: Female Genital Cosmetic Surgery: Solution to What Problem? Cambridge: Cambridge University Press; 2019.

28. Fausto-Sterling A. Sexing the body: gender politics and the construction of sexuality. NY: Basic; 2000.

29. Chase C. 'Cultural practice' or 'reconstructive surgery'? U.S. genital cutting, the intersex movement, and medical double standards.
In: James SM, Robertson C, editors. Genital Cutting and Transnational Sisterhood: Disputing U.S. Polemics. Urbana: U Illinois Press; 2002.

30. Green F. From clitoridectomies to 'designer vaginas': the medical construction of heteronormative female bodies and sexuality through female genital cutting. Sexual Evolut Gender. 2005;7(2):153-87.

31. Sullivan N. 'The price to pay for the common good': genital modification and the somatotechnologies of cultural (in)difference. Soc Semiot. 2007;17(3):395-409.

32. Nurka C. Female genital cosmetic surgery: deviance, desire and the pursuit of perfection. Cham: Palgrave Macmillan; 2019.

33. Jafar A. The thin line between surgery and mutilation. New York Times, 2019. https://www.nytimes.com/2019/05/02/opinion/fgmruling-intersex-surgery.html.

34. Liao LM, Wood D, Creighton SM. Parental choice on normalising cosmetic genital surgery: between a rock and a hard place. BMJ. 2015;351:h5124-5.

35. Clark-Flory T. Doctors warn that teen labiaplasty is on the rise. Vocativ, 2016. http://www.vocativ.com/313367/teen-labiaplastyis-on-the-rise/. Accessed 29 Aug, 2020.

36. Rabin RC. More teenage girls seeking genital cosmetic surgery. New York Times. 2016. https://well.blogs.nytimes.com/2016/04/ $25 /$ increase-in-teenage-genital-surgeryprompts-guidelines-fordoctors/.

37. Conroy R. Female genital mutilation: whose problem, whose solution? BMJ. 2006;333:106-7.

38. Boraei S, Clark C, Frith L. Labioplasty in girls under 18 years of age: an unethical procedure? Clin Ethics. 2007;3:37-41.

39. Dorneles de Andrade D. On norms and bodies: findings from field research on cosmetic surgery in Rio de Janeiro, Brazil. Reprod Health Matt. 2010;18(35):74-83.

40. O'Regan K. Labiaplasty: an investigation of the most popular trend in the field of 'vaginal rejuvenation' surgery. Guernica, 2020. https://www.guernicamag.com/daily/kirsten-oreganlabiaplasty-part-i/ ; https://www.guernicamag.com/daily/kirstenoregan-labiaplasty-part-ii/. Accessed 30 Aug, 2020.

41. Bragagnini Rodríguez P, Alvarez García N, González Ruiz Y, Ruiz de Temiño M, Escartín Villacampa R, González MartínezPardo N. Hypertrophy of labia minora: a growing problem in adolescence. Abstract. Cir Pediatr. 2015;28(4):196-9.

42. International Society of Aesthetic Plastic Surgery. ISAPS International survey on aesthetic/cosmetic procedures performed in 2018. ISAPS-Global-Survey-Results-208-new.pdf. Available from: www.isaps.org/medical-professionals/isaps-globalstatistics. Accessed 30 Aug 2020.

43. Hamori CA. Aesthetic surgery of the female genitalia: labiaplasty and beyond. Plast Reconstr Surg. 2014;134(4):661-73.

44. Hamori CA. Discussion: vaginal labiaplasty: current practices and a simplified classification system for labial protrusion. Plast Reconstr Surg. 2015;135(3):789-90.

45. Hamori CA. Discussion: why women request labiaplasty. Plast Reconstr Surg. 2017;139(3):864.

46. Oranges CM, Schaefer KM, Kalbermatten DF, Haug M, Schaefer DK. Why women request labiaplasty (letter). Plast Reconstr Surg. 2017;140(6):829e.

47. Runacres SA, Wood PL. Cosmetic labiaplasty in an adolescent population. J Pediatr Adolesc Gynecol. 2016;29:218-22.

48. Simonis M, Manocha R, Ong JJ. Female genital cosmetic surgery: a cross-sectional survey exploring knowledge, attitude and practice of general practitioners. BMJ Open. 2016;6(e103010):1-9.

49. BritSPAG. Labial reduction surgery (labiaplasty) on adolescents. britspag_labiaplastypositionstatement.pdf. Available from: www. rcog.org.uk/globalassests/documents/news/britspag. Accessed 29 Aug. 2020. 
50. Gonzales-Alabastro C, Eiber KS, Anger JT, Berman JR. Female cosmetic genital reconstruction: a review of current trends, treatments, and techniques. Curr Sex Health Rep. 2019;11:44-51.

51. American College of Obstetricians and Gynecologists, Committee on Adolescent Health Care. Opinion No. 686: Breast and labial surgery in adolescents. Obstet Gynecol. 2017;129:e17-9.

52. Hamori CA. Teen labiaplasty: a response to the May 2016 American College of Obstetricians and Gynecologists (ACOG) recommendations on labiaplasties on adolescents. Aesthetic Surg. 2016;36(7):807-9.

53. Michala L. The adolescent and genital dissatisfaction. Clin Obstet Gynecol. 2020;63:3528-35.

54. UNICEF Female Genital Mutilation. https://www.unicef.org/ protection/female-genital-mutilation, updated March 2020. Accessed 30 Aug 2020.

55. Aesthetics Society (formerly ASAPS). AestheticSociety_Stats2019Book_FINAL.pdf. Available from: https:// www.surgery.org/media/statistics. 26 Aug 2020.

56. Essen N, Johnsdotter S. Female mutilation in the West: traditional circumcision versus genital cosmetic surgery. Acta Obstet Gynaecol Scand. 2004;83:611-3.

57. Braun V. The women are doing it for themselves': the rhetoric of choice and agency around female genital 'cosmetic surgery. Aust Fem Stud. 2009;24(60):233-49.

58. Cox LJ. Ethics, aesthetics and euphemism: the vulva in contemporary society. J Fam Plann Reprod Health Care. 2016;42:226-9.

59. Chambers C. Choice and female genital cosmetic surgery. In: Female Genital Cosmetic Surgery: Solution to What Problem? Cambridge: Cambridge University Press; 2019.

60. Rogers $\mathrm{J}$. The first case addressing female genital mutilation in Australia: where is the harm? Alternat Law J. 2016;41(4):235-8.

61. Gunning IR. Arrogant perception, world-travelling and multicultural feminism: the case of genital surgeries. Columbia Human Rights Law Rev. 1992;23(8):188-248.

62. Njambi WN. Dualisms and female bodies in representations of African female circumcision: a feminist critique. Fem Theory. 2004;5(3):281-303.

63. Douglas M. Purity and danger. London: Routledge and Kegan Paul; 1966.

64. Jones M. Expressive surfaces: the case of the designer vagina. Theory Cult Soc. 2017;34(7-8):29-50.

65. Rodrigues S. From vaginal exception to exceptional vagina: the biopolitics of female genital cosmetic surgery. Sexualities. 2012;15(7):778-94.

66. Braun V, Wilkinson S. Socio-cultural representations of the vagina. J Reprod Infant Psychol. 2001;19(1):17-32.

67. Tiefer L. Female genital cosmetic surgery: freakish or inevitable? Analysis from medical marketing, bioethics, and feminist theory. Fem Psychol. 2008;18(4):466-79.

68. Moran C, Lee C. What's normal? Influencing women's perceptions of normal genitalia: an experiment involving exposure to modified and unmodified images. BJOG. 2014;121(6):761-6.

69. Kristeva J. Powers of horror: an essay on abjection. Roudiez LA, translator. New York: Columbia UP; 1982.

70. Braun V. Selling a perfect vulva? Selling a 'normal' vulva! In: Female Genital Cosmetic Surgery: Solution to What Problem? Cambridge: Cambridge University Press; 2019.

71. Oeming M. In vulva vanitas: the rise of labiaplasty in the West. Gender Forum. 2018;67:70-91.

72. Rosaldo M, Lamphere L, editors. Woman, culture and society. Stanford: Stanford UP; 1974.

73. Reiter R, editor. Toward and anthropology of women. New York: Monthly Review Press; 1975.

74. Rubin G. The traffic in women: notes on the political economy of sex. In: Reiter R, editor. Toward and anthropology of women. New York: Monthly Review Press; 1975.
75. Bordo S. Unbearable weight: feminism, Western culture, and the body. Berkeley: U California Press; 1993.

76. Butler J. Gender trouble: feminism and the subversion of identity. NY: Routledge; 1990.

77. Butler J. Bodies that matter: on the discursive limits of 'sex'. NY: Routledge; 1993.

78. Bourdieu P. The logic of practice. R. Nice, translator. Stanford: Stanford UP; 1990.

79. Braun V. Female genital cosmetic surgery: a critical review of current knowledge and contemporary debates. J Women's Health. 2010;19(7):1393-407.

80. McDougall LJ. Towards a clean slit: how medicine and notions of normality are shaping female genital aesthetics. Cult Health Sex. 2013;15(7):774-87.

81. Simonis M. Female genital cosmetic surgery and the role of the general practitioner. In: Female Genital Cosmetic Surgery: Solution to What Problem? Cambridge: Cambridge University Press; 2019.

82. Schick VR, Rima BN, Calabrese SK. Evulvaluation: the portrayal of women's external genitalia and physique across time and the current Barbie doll trends. J Sex Res. 2011;48(1):74-81.

83. Cain JM, Iglesia CB, Dickens B, Montgomery O. Body enhancement through female genital cosmetic surgery creates ethical and rights dilemmas. Int J Gynecol Obstet. 2013;122:169-72.

84. Moran C, Lee C. 'Everyone wants a vagina that looks less like a vagina': Australian women's views on dissatisfaction with genital appearance. J Health Psychol. 2018;23(2):229-39.

85. Sharp G, Tiggeman M, Mattiske J. Predictors of consideration of labiaplasty: an extension of the tripartite influence model of beauty ideals. Psychol Women Q. 2015;39(2):182-93.

86. Koning M, Zeijlmans IA, Bouman TK, van der Lei B. Female attitudes regarding labia minor appearance and reduction with consideration of media influence. Aesthet Surg J. 2009;29(1): 65-71.

87. Yurteri-Kaplan LA, Antosh DD, Sokol AI, Park AJ, Gutman RE, Kingsberg SA, et al. Interest in cosmetic vulvar surgery and perception of vulvar appearance. Am J Obset Gynecol. 2012;207(5): 428e1-7.

88. Sharp G, Tiggeman M, Mattiske J. Factors that influence the decision to undergo labiaplasty: media, relationships, and psychological well-being. Aesthet Surg J. 2016;36(4):469-78.

89. Rouzier R, Louis-Sylvestre C, Paniel B, Haddad B. Hypertrophy of the labia minora: experience with 163 reductions. Am J Obstet Gynecol. 2000;182:35-40.

90. Goodman MP. Female genital cosmetic and plastic surgery: a review. J Sex Med. 2011;8:1813-25.

91. Surroca MM, Miranda LS, Ruiz JB. Labiaplasty: a 24-month experience in 58 patients: outcomes and statistical analysis. Ann Plast Surg. 2018;80(4):316-22.

92. Bramwell R, Morland C. Genital appearance satisfaction in women: the development of a questionnaire and exploration of correlates. J Reprod Infant Psychol. 2009;27(1):15-27.

93. Liao LM, Creighton SM. Female genital cosmetic surgery: a new dilemma for GPs. Br J Gen Pract. 2011;61(582):7-8.

94. McCartney J. Great Wall of Vagina. https://jamiemccartney.con/ pportfolio/the-great-wall-of vagina, Last accessed 1 Sept 2020.

95. Gress S. Aesthetic and functional labiaplasty: Springer International; 2017. https://doi.org/10.1007/978-3-319-60222-6. 24 Aug 2020.

96. Crouch N. Female genital anatomy. In: Female Genital Cosmetic Surgery: Solution to What Problem? Cambridge UP; 2019.

97. Lloyd J, Crouch N, Minto CL, Liao LM, Creighton S. Female genital appearance: 'normality' unfolds. BJOG. 2005;112:643-6.

98. Clerico C, Lari A, Mojallal A, Boucher F. Anatomy and aesthetics of the labia minora: the ideal vulva? Aesthet Plast Surg. 2017;41: 714-9. 
99. Sorice S, Li AY, Canales FL, Furnas HJ. Why women request labiaplasty. Plast Reconstr Surg. 2017;139(4):856-63.

100. Rodriquez SB. The history of female genital cosmetic surgery in the United States: from marginal to mainstream. In: Female Genital Cosmetic Surgery: Solution to What Problem? Cambridge: Cambridge University Press; 2019.

101. Kreklau A, Vâz I, Oehme F, Strub F, Brechbühl R, Christmann C, et al. Measurements of a 'normal vulva' in women aged 15-84: a cross-sectional perspective single-centre study. BJOG. 2018;125: 1656-61.

102. Munhoz AM, Filassi JR, Ricci MD, Aldrighi C, Correia LD, Aldrighi JM, et al. Aesthetic labia minora reduction with inferior wedge resection and superior pedicule flap reduction. Plast Reconstr Surg. 2006;118:1237-47.

103. Smarrito S. Classification of labia minora hypertrophy: a retrospective study of 100 patient cases. JPRAS Open. 2017;13:8191. https://doi.org/10.1016/jpra.2017.05.013.

104. Triana L. Commentary on anatomy and aesthetics of the labia minora: the ideal vulva? Aesthet Plast Surg. 2017;41:993-4.

105. Hacking I. Making up people. In: Lock M, Farquhar J, editors. Beyond the Body Proper: Reading the Anthropology of Material Life. Durham: Duke University Press; 2007.

106. Braun V. In search of (better) sexual pleasure: female genital 'cosmetic' surgery. Sexualities. 2005;8(4):407-24.

107. Drysdale K. Healing it to a single crease. http://www.abc.net.au/ tv/hungrybeast/blog/kdrysdale/healing-it-single-crease. March 3 2010. Printed 10 Aug 2016. No longer on line 29 Aug 2019.

108. Bramwell R. Invisible labia: the representation of female external genitals in women's magazines. Sex Relatsh Ther. 2002;17(2): 187-90.

109. McBride H. Aesthetic labiaplasty is never just a 'choice'. Feminist Current, 14 Jan 2016. http://www.feministcurrent.com/2016/01/ 14/labiaplasty-never-a-choice/. Accessed 30 Aug 2020.

110. Coughlin S. A very NSFW look at what fuels the labiaplasty industry. http://www.refinery29.com/2016/01/101315/ labiaplasty-industry-porn-photoshop. Accessed 30 Aug 2020.

111. Jones B, Nurka C. Labiaplasty and pornography: a preliminary investigation. Porn Stud. 2015;2(1):62-75.

112. Veale D, Eshkevari E, Ellison N, Costa A, Robinson D, Kavouni A, et al. A comparison of risk factors for women seeking labiaplasty compared to those not seeking labiaplasty. Body Image. 2014;11:57-62.

113. Veale D, Eshkevari E, Ellison N, Costa A, Robinson D, Kavouni A, et al. Psychological characteristics and motivation of women seeking labiaplasty. Psychol Med. 2014;44:555-66.

114. Nurka C, Jones B. Labiaplasty, race and the colonial imagination. Aust Fem Stud. 2014;28(78):417-42.

115. Placik OJ, Arkins JP. Plastic surgery trends parallel Playboy magazine: the pudenda preoccupation. Aesthet Surg J. 2014;34(7): 1083-90.

116. Tiefer L. Feminist activism to challenge the new industry of female genital cosmetic surgery. In: Female Genital Cosmetic Surgery: Solution to What Problem? Cambridge: Cambridge University Press; 2019.

117. RealSelf.com. https://www.realself.com/photos/labiaplasty. Accessed July 262020.

118. Nuffield Council on Bioethics. Cosmetic procedures: ethical Issues; 2017. www.nuffieldbioethics.org/publications/cosmeticprocedures. Accessed 29 Aug 2020.
119. Michala L. Clinical evidence of the effects of female genital cosmetic surgery. In: Female Genital Cosmetic Surgery: Solution to What Problem? Cambridge: Cambridge University Press; 2019.

120. Labiaplasty.com. Botched Labiaplasty; 2017 https:/labiaplasty. com/botched-labiaplasty/ Accessed 30 Aug 2020.

121. Revision of botched labiaplasties -AlterMD, Dr. Alter's before and after of botched labiaplasties. https://www.altermd.com/ before-after/labiaplasty-reconstruction-surgery/ Accessed 30 Aug 2020.

122. Royal College of Obstetricians and Gynaecologists (RCOG). Ethical considerations in relation to female genital cosmetic surgery (FGCS). RCOG Ethics Committee; 2013. Available from https://www.rcog.org.uk/globalassets/documents/guidelines/ ethics-issues-and-resources/rcog-fgcs-ethical-opinion-paper.pdf

123. Turini T, Weck Roxo AC, Serra-Guimarãres F, Abreu ML, Cardoso de Castro C, Aboudhib JH, et al. The impact of labiaplasty on sexuality. Plast Reconstr Surg. 2018;141:87-92.

124. Placik OJ, Arkins JP. A prospective evaluation of female external genital sensitivity to pressure following labia minora reduction and clitoral hood reduction. Plast Reconstr Surg. 2015;136: $442 \mathrm{e}-52 \mathrm{e}$.

125. Obermeyer CM. Female genital surgeries: the known, the unknown, and the unknowable. Med Anthropol Q. 1999;13(1):79106.

126. Obermeyer CM. The health consequences of female circumcision: science, advocacy, and standards of evidence. Med Anthropol Q. 2003;17(3):394-412.

127. Gruenbaum E. The cultural debate over female circumcision: the Sudanese are arguing this one out for themselves. Med Anthropol Q. 1996;10:455-75.

128. Kimani S, Shell-Duncan B. Medicalized mutilation/cutting: contentions practices and persistent debates. Curr Sex Health Rep. 2018;10:25-34. https://doi.org/10.1007/s11930-018-0140-y.

129. Kimani S, Kabiru CW, Muteshi J, Guyo J. Female genital mutilation/cutting: emerging factors sustaining medicalization related changes in selected Kenyan communities. PLoS One. 2020;15(3): $\mathrm{e} 0228410$.

130. O’Mathúna D. Erecting new goals for medicine: Viagra and medicalization. In: Botz-Bornstein, editor. The Philosophy of Viagra: Bioethical Responses to the Viagrification of the Modern World. Amsterdam: Rodopi; 2011.

131. Conrad P. The medicalization of society: on the transformation of human conditions into treatable disorders. Baltimore: Johns Hopkins UP; 2007.

132. Weeks J. Viagra. In: Weeks J, editor. The Language of Sexuality. London: Routledge; 2011.

133. Ferguson J. The anti-politics machine. Minneapolis: University of Minnesota Press; 1994.

134. El-Gibaly O, Aziz M, Abou HS. Health care providers' and mothers' perceptions about the medicalization of female genital mutilation or cutting in Egypt: a cross-sectional qualitative study. BMC Int Health Hum Rights. 2019;19:19-26. https://doi.org/10. 1186/s12914-019-0202-x.

135. WhatClinic.com, https://www.whatclinic.com/. Last accessed 30 Aug.2020.

Publisher's Note Springer Nature remains neutral with regard to jurisdictional claims in published maps and institutional affiliations. 